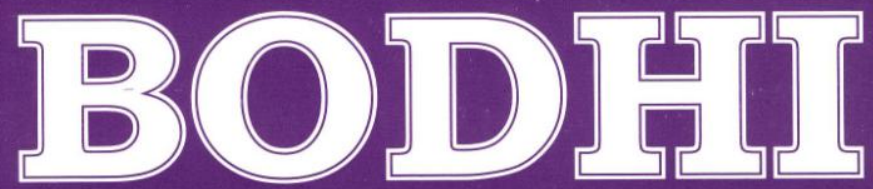

An Interdisciplinary Journal

ISSN: 2091-0479

Department of Languages and Mass Communication School of Arts

Kathmandu University

Bodhi, 4 (1), 48-70. ISSN 2091-0479. (C) 2010 Kathmandu University 


\section{The correlation between media and technology: The context of the gradual rise of new media ${ }^{1}$}

- Radka Kohutova

\section{Introduction}

New media go inseparably with the new economy, and alter our daily lives. They still oscillate between being considered absolutely fascinating by some and almost terrifying by others. Their gentle and rather slow rise has been noticed since the 1950s and 1960s. The solid-state designed computers were introduced to the general public in the 1960s (though the socalled first generation of computers appeared already after World War II), but only a pure decade later, since 1970s, we can already speak about the age of microcomputer components.

The early thinking about new media mostly focused on the comparison of the characteristic features of new media technologies with the older or traditional (analogue) media. ${ }^{2}$ Some authors portrayed the rise of new media as a rebellion against mass production (Enzersberger, 1970). Similarly, as general thinking about new media changed over the decades, the changes and different trend in the conceptualization of new media have also been apparent to date, mainly in relation with media convergence. ${ }^{3}$ The new media technology has been changing in amazing pace.

The relationship between society on one side, and a computer as an example of a new communication medium par excellance on the other, initiated the interest of many mass communication (not exclusively) researchers since the early 1960s. E. Parker

\footnotetext{
${ }^{1}$ The article was supported by the SVV No. 261501

${ }^{2}$ In this connection, Negroponte (1995) distinguished between atoms (newspapers, books, magazines) and more valuable bits (new media).

${ }^{3}$ Cf. Pool (1983); Jenkins (2006).
} 
can be called a pioneer in new media research - from a communication perspective. As a student of W. Schramm, Parker focused on the new media effects. (Rice, 1984a) Simultaneously, he was using the computer as a tool for his research of media effects of television, which can also be considered pioneering in computer assisted data processing, its analysis and evaluation. (Schramm, Lyle \& Parker, 1961)

The primary aim of this article is to focus on the coverage of the framework opinions on the complex interaction between society and new communication technologies between 1920 and 1970. The debate on mapping the state of new (and even newer) media technologies and their further development, as well as the mutual reciprocal technology-media-society triangle, came to light in early $1920 \mathrm{~s}$ - also the decade of the rise of systematic media research. Since the 1970s, and even more noticeably in the 1980s, we have been able to speak about the evident rise of new media, as we understand it now, which goes hand in hand with raising new questions about its impact on society. One of the most dominant and influential concepts of the examined period is technological determinism and its subcategory media determinism.

Since 1980s, technological determinism began to diminish between scholars and, as some of them claimed, was replaced by social determinism. (MacKenzie a Wajcman, 1999 [1985]; Lievrouw, 2006). New media studies further reflected its multidisciplinary character while being influenced by postmodern and post-industrial theories, including the broad concept of information society. (Lievrouw \& Livingstone, 2006) Nevertheless, the fellowship with the idea of technological determinism is apparent even in later works of communication studies researchers. ${ }^{4}$

${ }^{4}$ cf. Manovich, 2001; Poster, 1990; Postman, 1979, 1993 [1992] 


\section{Mass culture in modern society}

Mass media play a crucial and key role in modern, industrial but also later in post-industrial society. The beginning of the $20^{\text {th }}$ Century was still under the influence of industrialization and manufacturing as its distinctive feature, and urbanization. Mass media - mass production with unified content - mass culture with a crucial role of profit were all dynamically developing. The leading position within mass media was held by the press.

Rakow later remembered the euphoria which accompanies development of each communication technology: "Once the initial introductory phase of a new technology - telephone, movies, radio, television, video games - has passed and the technology has become a consumer product, dominant groups, including academics, have framed concerns about media around media reception, and in terms of their effects on people" (Rakow, 1999, p. 76).

The technological development had an undeniable impact on the natural and social environment in modern society as much as on human's comprehension of the surrounding world. "The first third of the twentieth century witnessed the arrival and proliferation of innovative 'representational technologies', which included the tabloid press, photography, film, radio, and the gramophone" (Rieger, 2005, p. 3). As Rieger continues, each technological innovation launched public debate.

The new media of that time - radio and several years later television, stimulated the social science research in the $20^{\text {th }}$ century, which was focused on their organization, audience, content but also effects on both individuals and society. (Rice, 1984a). The channel was a key component in the early linear models of communication (e.g. Shannon \& Weaver, 1949). "One need not be a technological determinist to agree that the medium may be a fundamental variable in the communication 
process even if a 'medium' may be media-independent, such as videotext" (Rice, 1984a, p. 20).

The research on mass media effects between 1920 and 1970 has historically passed several phases. Between the two World Wars, media were still considered all-powerful. This view came simply from the general popularity of press, film and radio and was not based on empirical and systematic research (McQuail, 2010). The first attempts to investigate the media effects were rather in purely theoretical considerations and some of those authors is possible to call key figures in media studies in $20^{\text {th }}$ Century. ${ }^{5}$

This phase was later replaced by the empirical phase at the end of 1930s. The media effect should have been proved by researchers and their surveys. Many separate studies with different results were carried out. As Berelson (1948) nicely summarized: "Some kinds of communications on some kinds of issues, brought to the attention of some kinds of people under certain kinds of conditions have some kinds of effects" (Berelson, 1948).

The Bureau for Applied Social Research (BASR), a research institute at Columbia University founded by Austrian emigrant P. F. Lazarsfeld in 1944, played a crucial role in a history of mass communication research and in media studies generally. Their studies and publications were based on innovative methodologies within the area of quantitative analysis. Two studies from this time became legendary: The Erie County Study (1940) and The Decatur Study (1944). They represented basis for the later published books The People's Choice (1948) and Personal Influence (1955) where the concept of opinion leadership was introduced. Nevertheless, this second phase in history of media effects led into disappointment as the direct effects of media were not proved sufficiently. The phase was

${ }^{5}$ See W. Lippmann's Public Opinion (1965) [1922] or R. E. Park's The Immigrant Press and Its Control (1922). 
replaced by the reentered belief in powerful media with an alteration that the presumed effect is rather long-term. This phase ended around 1975 (Bryant, Oliver, 2009 [1994]).

\section{The Frankfurt School}

The critical voices of mass culture are apparent in Germany since 1920s and later became known as Frankfurt School. Vast majority of representatives of Frankfurt School are directly or indirectly connected with Institute for Social Research (Institut für Sozialforschung) founded in 1923 in Frankfurt am Main and affiliated with the Johann Wolfgang Goethe University.

The first generation of scholars from Frankfurt School, also called Critical Theory (Kritische Theorie), is represented by M. Horkheimer, T. Adorno, E. Fromm, H. Marcuse or W. Benjamin. The scholars drew on a socio-economic Marxist tradition, and therefore are often referred to as neo-Marxist school, as well as on S. Freud's psychoanalysis which they brought to social theory. Beside that, we can trace the influence of Hegel's philosophy and more generally also the heritage of the German Enlightenment.

The representatives of Frankfurt School consider unification of culture and industry as an implication of development of modern society. The uniqueness and individuality had been replaced by the mass in their eyes which is best described by the phenomenon of culture industry. The audience is considered being passive in receiving mediated messages. Besides the critical view of mass society, the criticism of the western industrial society is presented. According to it, people are exposed to the new technologies and their increasing significance cannot be avoided. The world is driven by technological principle and its rationality. The individuality is being lost. The culture is under the influence of vulgar materialism and ideology (Adorno, 1951). The last mention topic resulted from the experience with Nazism, its propaganda 
and technocratic society. Therefore, the European view on the effect of new media technologies at that time was more negative, especially in comparison with the American view.

In 1920s, B. Brecht (1932) called for the radio which would be changed from an apparatus for distribution to communication ${ }^{6}$. This would support a democratic mode of communication in media. Several years later, W. Benjamin (2003) took similar view on the merit while wishing for a more opened approach from mass media towards their audience. The audience should have got a chance to become active via the interactive mass media.

Benjamin (2003) addressed new technologies in relation to art. He founded an important change in the nature of the audience, no longer consisting of individuals but transformed into masses. He said, "The masses are a matrix, out of which all the customary modes of conduct towards art-works are today being reborn" (2003, p. 267). It is the technological reproducibility of the work which transforms the relationship of masses to media.

New technological possibilities, new media forms (especially photography, film and radio) lead to decay of the aura of the work of art. The aura is inseparably connected with its unique spatio-temporal dimension, here-and-now (Hier und Jetzt), which reproductions miss. Benjamin (1982) considered technologies marginally under the influence of Brecht (who he is referring to) also in his previous essay Der Autor als Produzent which primarily focused on the role of literature in the socialistic society.

Marcuse (1982) was concerned with social impacts of modern technologies. His position and ideas on technology were influenced to a great extent by his teacher Heidegger. On the

\footnotetext{
${ }^{6}$ McMillan (2002) draws attention to "the strong parallel between the development of the radio and development of the Internet in terms of cultural history" with reference to other authors such are (Douglas, 1987; Lappin, 1995). Also Deuze $(1999,2003)$ took similar view.
} 
other hand, Marcuse criticized Heidegger for his too vague expressions. Marcuse approached the concept of technology in similar way as Heidegger's "a social process". Technology includes but goes beyond "technics" which he understood as "the technical apparatus of industry, transportation, communication." Technology, between others, characterizes "the machine age"; it facilitates to organize, perpetuate but also change social relationship. It can promote both authoritarianism and liberty $^{7}$ (Marcuse, 1982, pp. 138-139).

The technological process introduced a brand new understanding of rationality (as opposed to the traditional rationality $)^{8}$ and new standards of individuality. Individualism here represented the contradictory concept to mass society. "These changes are not the (direct or derivative) effect of machinery on its users or of mass production on its consumers; they are rather themselves determining factors in the development of machinery and mass production" (Marcuse, 1982, p. 139). While for Marcuse the individual is determined by "a sequence of semi-spontaneous reactions to prescribed mechanical norms," he did not see the technological process itself as necessarily negative in its implication but rational (or even reasonable). It could eventually save time and energy to individuals which would otherwise be wasted for a pure life maintenance and rush to produce life necessities (Marcuse, 1982, p.143). "The less time and energy man has to expend in maintaining his life and that of society, the greater the possibility that he can 'individualize' the sphere of his human realization" (Marcuse, 1982, p. 161). As Marcuse further concluded, this is just a Utopia which would not ensure happiness to people as they will be left with time for their sorrows.

\footnotetext{
${ }^{7}$ In this context, Marcuse turned his attention to thinking about "technocracy" of the Third Reich.

${ }^{8}$ Marcuse (1964) elaborated on his ideas about technological racionality further again after twenty years.
} 


\section{The Chicago School}

Reflections on correlation between media and society can be found in writing of intellectuals on North American continent too. University of Chicago, with its prestigious sociology department founded in 1892, can be marked as a significant centre of such reflections. Its fruitful times regarding academic research (mainly in urban sociology with a focus on ethnography) dated back to 1920 s and 1930s. While the European voices commenting the new communication technologies at that time sounded quite pessimistic mainly in light of the historical context, the American view took completely different, optimistic approach. Innovations in media technologies were welcomed here.

The Chicago School addressed the changes which were taking place within the society and people's daily lives; industrialization was accompanied by urbanization; the American urban culture had to react to the rapid, hardly controlled increase of immigrants. The society faced to the increased criminality, prostitution and other social-pathological phenomena. Using terminology of German sociologist F. Tönniese (2002), Gemeinschaft (community), built up on kinship and family bonds, was being transformed into the lack of solidarity and isolation in Gesellschaft (society).

R. E. Park (1925), one of the most prominent and influential researchers representing the Chicago School, formalized his ideas on the media/society relationship even though rather indirectly and quite probably under the influence of his previous job as a journalist. In his major work dated back to 1915, The City: Suggestion for the Investigation of Human Behavior in the Urban Environment, he viewed modern technologies as influential on shaping the society. ${ }^{9}$ Park further

\footnotetext{
${ }^{9}$ Several years later, H. Innis was strongly influenced by thoughts of Chicago School where he himself studied. His work bears remarks of direct influence of R. E. Park, even though H. Innis had never attended his lectures.
} 
explored this idea in 1940 in the article "Physics and Society," and later on in his book Society from 1955.

Researchers from Chicago School were significantly influenced by philosophy of pragmatism of J. Dewey who himself joined the University of Chicago for 10 years. Dewey did not present his ideas on technologies systematically but they can be found scattered across his texts. Besides being interested in relationship of technologies in human lives, Dewey was fascinated also by the correlation of technology and sciences. Technological progress, which Dewey saw as beneficial for the whole society, was sustained by both human knowledge and wishes and supported by the economic interests. ${ }^{10}$

\section{From technological to media determinism}

The historical roots of socio-philosophical concept of technological determinism can be encountered on European continent. Technologies, with a special emphasis on the 'newer' ones, determine the evolution of society under this concept. Technological determinism presumes a causal connection between the nature of technologies and the nature of a society; in other words, between the technological development and the social changes. It is based on the assumption that the new technologies serve as the force driving the society and determining the social change. It has also impact on humans' interactions.

On the other hand, the critics of technological determinism challenge this idea while refusing that it is just technology which shapes the society, gives it the base and draws our future. Chandler (1995) summarized both supportive and declinatory arguments on technological determinism and noted that their main difference lies in stressing technology over the society and vice versa. Major critics and supporters of media determinism can be found not only between media theoreticians but also

${ }^{10}$ Cf. Levin (1956), Hickman (1990). 
between sociologists, historians, anthropologists and economists.

Regarding the deterministic view of technology, two varieties shall be mentioned, the soft and hard determinism (Heilbroner, 1994; Smith, 1994). "Technological determinism gives us a framework of explication that ties together the background forces of our civilization, in which technology looms as an immense presence, with the foreground problem of the continuously evolving social order in which we live" (Heilbroner, 1994, p. 77). The hard determinism ${ }^{11}$ assumes that technological progress is completely autonomous and inevitable; soft determinism ${ }^{12}$ still highlights the technological force in the social evolution, but less fatal.

Bimber (1994) challenges Heilbroner's classification and alternatively offered three interpretations of technological determinism: normative, nomological and unintended consequences. Bimbers calls nomological account as a pure technological determinism where the future events are causally determined by preceding events or natural law. ... technological developments occur according to some naturally given logic, which is not culturally or socially determined, and that these developments force social adaptation and changes (Bimber, 1994, p. 84).

For Bimber, Heilbroner represented Nomological account with his essay from 1967 called "Do Machines Make History?" Heilbroner stated there that technology determines the course of human events. Nevertheless, Heilbroner considered himself a follower of soft determinism. Bimber noted that Heilbroner's later ideas on technological determinism moved towards normative approach using his vocabulary. ${ }^{13}$

\footnotetext{
${ }^{11}$ Cf. Ellul (1964), Mumford (1964, 1970), Winner (1977).

${ }^{12}$ Cf. Heilbroner (1994).

${ }^{13}$ Ellul (1964) and Habermas (1970) also represented normative approach in the Bimber's view.
} 
K. Marx is sometimes referred to as historically the first technological determinist, mainly to his quote from 1847: "The windmill gives you society with the feudal lord: the steam-mill, society with the industrial capitalist" (Marx, 2005, p. 119. On the other hand, other scholars disagreed with that and debated that Marx is economic determinist. ${ }^{14}$

Technological determinism as a term is believed to be coined by T. Veblenovi. (Ellul, 1964; Jones, 1990). For Veblen, the transmision to modernism is characterized by machine technology (Veblen, 1978). Veblen indicated the inclination to the impersonal life as an implication of the industrial revolution: "...the course of things is given mechanically, impersonally, and the resultant discipline is a discipline in the handling of impersonal facts for mechanical effect" (ibid, 148).

Built on Veblen's heritage, J. Ellul published his extremely critical book La Technique, ou, L'enjeu du siècle in 1954. As Ellul put it, the new technological world represented a threat for people. He called it the diagnosis for which the remedy had not been found yet (Ellul, 1964, p. xxxi). "Technique has become autonomous; it has fashioned an omnivorous world which obeys its own laws and which has renounced all tradition" 15 (ibid, p. 14). It is not the society which forms new technologies but technologies themselves. ${ }^{16}$ According to Ellul, new technologies transform the relationship between humans and nature; technological environment substituted the natural and became not only determining but completely independent on a man, even controlling both men and a society.

\footnotetext{
${ }^{14}$ See Bimber (1994) for summary of both groups.

${ }^{15}$ Ellul used terms technique and technology quite promiscuosly. For him, the technique is a broader term including not only technology but also machines or organization of work.

${ }^{16}$ This assumption was criticized by some scholars who argue that the technological autonomy is unimaginable as technology is invented by society and therefore under its influence. (See Benthall, 1976)
} 
V. C. Ferkiss (1969), a supporter of Ellul, a critic of McLuhana, takes the similar view of technological changes and their impact on society as whole. As Ferkiss puts it, it is our approach to technologies which differs us from our ascendants. $\mathrm{He}$ introduced the term technological man. Technology intervenes all spheres of our lives and sneaks into the inner world of a man.

Ferkiss (1969) warned that the contemporary technological man is observed via the old, bourgeois values. At the same time, it is a technological man himself who considers technologies especially important. "While it is untrue that technology determines the future independently of human volition, there is no question that human individuals and human society are increasingly under pressure to conform to the demands of technological efficiency, and there is a real possibility that the essence of humanity will be lost in the process, that human history will come to an end and be converted into a mere prelude to the history of a posthuman society in which machines rather than men rule" (Ferkiss, 1974, p. 5). Ferkiss claimed that it is up to a man to realize that he is and shall be dominating to machines and also bear the responsibility for the evolution.

\section{The Toronto School}

The Toronto School of Communication belongs to mediacentric theories of society and represents media determinism. McQuail (2010, p. 103) summarized the grounds of media determinism in four propositions: 1) communication technologies are fundamentally important for the society; 2) each technology has a bias towards specific media forms, their content and recipients; 3) the social change, its direction and rate depends on the sequence of invention followed by the usage of communication technology; 4) communication revolutions lead to social revolutions. 
This tradition is especially closely linked to names such are H. Innis, M. McLuhan (both will be discussed more in detail bellow), E. S. Carpenter, N. Frye and E. Havelock (1963). Innis and McLuhan both introduced their own approaches and understanding of new media technologies. They addressed their role in the communication process and influenced dozens of scholars. "Innis and McLuhan both argue that the technology used for communication impacts upon the perception and importance of space and time: some technologies are predisposed to communicating across space (e.g. paper), while others persist through time (e.g. stone)" (Green, 2002, p. 63).

Innis was attracted by the study of social history of communication and media which was strongly reflected in his work. He examined media as technological artifacts. Innis (1951) assumed a direct link between the stability of a society and a balance of various media. Technology and society are in a dialectical interrelationship. Innis argued that some societies, based on their form, have a tendency to incline toward encouraging new media forms, their arrival and institutionalization. Regarding this view, Innis is often assigned as a representative of technological determinism within media studies (e. g. McQuail, 2010). McLuhan and his introduction to Innis's book The Bias of Communication contributed to this view. As McLuhan put it, Innis used a history “... as ascientific laboratory, as a set of controlled conditions within which to study the life and nature of forms..." (ibid, p. x).

Some scholars argue that to consider Innis as a technological determinist is a wrong interpretation and simplification of his complex texts and arguments (similarly as in the case of McLuhan). As the critics of such a typology put it, Innis did not consider technology as a source of a social (r)evolution but understood it as an important factor in shaping and influencing the culture of given society (cf. Soules, 1996; Blondheim, 2007). Innis can be called a technological realist from this point of view. "Technology as the source of social change is the exception, not the rule" (Blondheim, 2007, p. 65). 
Yet, Innis did not deny the "significance of communication" in relation to the human civilizations (Innis, 1964, p. 3). Each medium helps to spread the knowledge across the space and time. The spatio-temporal dimension served Innis as a tool to distinguishing between space-binding and time-binding media. ${ }^{17}$ Society is dependant on the media technology which it chooses (or in his words is biased towards a certain medium) and according to that it is either sustained over time and rises (time-binding) or falls (space-binding) (Innis, 2007).

No matter whether we agree or not that Innis was a technological determinist, there is general consensus that $\mathrm{M}$. McLuhan was a technological/media determinist par excelance. McLuhan is well-known for his techno-centric view on the relationship between media and society. He made frequent references to Innis' work who he, yet critically, admired and often seeked inspiration in. ${ }^{18}$

McLuhana can be called a technological visionary. Speaking about the "communication revolution", it is new media (even though this term was used in relation with electronic media in 1950s) that have certainly brought us there. That all together only highlighted the concept metaphorically called a global village. In 1970, McLuhan modified this concept (which was a reaction to electronic media and mainly to television) in a book co-authored by Watson, and with a knowledge of new technologies (e.g. satellites) introduced a new metaphor, the global theatre.

McLuhan attempted to approach new technologies without any bias. He understood a technological development as natural and claimed that it shall be studied, not judged, neither criticized. $\mathrm{He}$ observed that the press is a technology supporting

\footnotetext{
${ }^{17}$ McLuhan's classification on hot and cold media is drawn in this one.

${ }^{18}$ The medio-centric ideas on relationship between society and media technology of Innis and McLuhan were followed by Ong (1982); Meyrowitz (1985); Thompson (1995).
} 
individualism. "If men decided to modify this visual technology by an electric technology, individualism will also be modified. To raise a moral complaint about this is like cussing a buzz-saw for lopping off fingers. 'But,' someone says, 'we didn't know it would happen.' Yet even witlessness is not a moral issue. It is a problem, but not a moral problem; and it would be nice to clear away some of the moral fogs that surround our technologies. It would be good for morality" (McLuhan, 2002, p. 158).

"The medium is the message" is the phrase McLuhan is probably best remembered for ${ }^{19}$ (McLuhan, 1967). McLuhan started with a premise that the form, the channel via the message is transmitted, is more important than its content. Medium itself - the technological apparatus is communication. McLuhan's usage of the term technology was very broad, similarly in case of communication technologies. The language as well as each medium was a technology in his view. McLuhan suggested that media as technologies are the extensions of human bodies and stated that each society is characterized by its media and the senses they extend. He categorized media as hot, which dominantly extend one sense over the others and presume our low participation (mostly the older media forms, starting with typography), and cold media supporting the social interaction, such are new media. New media are not a challenge only to the older media forms but also for us as their recipients.

\section{Conclusion}

Some of the contemporary scholars consider technological determinism, as a media paradigm, obsolete (MacKenzie a Wajcman, (1999); Marshall, 2004). Others claim that we have gotten to the era of neo-technological determinism (Ferguson, 1996). According to Heilbroner (1994), it is not necessary to

\footnotetext{
${ }^{19}$ Negroponte polemized with this statement about 30 years later, saying that the medium in not the message in the digital world anymore. Negroponte pointed out the move from medium towards message. Digital data in form of bits in a message can be stored, reused or transformed into other media. (Negroponte, 2001)
} 
ask any more whether machines make history but how they make it. "Of course we would expect that the transition from feudalism to capitalism was profoundly connected with the rise of a new level of technological capability. But precisely what does 'profoundly' mean?" (Heilbroner, 1994, p. 70).

Innovations in technology contribute to evolution. The contemporary Western society is more and more dependent on modern technologies. The questions on clarification of the correlation between technologies, society and its culture returned with a rise of networked society. Marshall (2004) noted to McLuhan's theories and visions on media: "Some of these ideas actually make more sense when they are linked to new media technology than they do to any of the technologies contemporaneous with McLuhan between 1950s and 1970s" (Marshall, 2004, p. 31).

New media represent a dynamic concept ${ }^{20}$, which attracts attention of the contemporary researcher not only from media studies. This paper summarized the framework opinions on the technological development in media studies between 1920 and 1970, before the rise of networked communication. Those works and ideas are still very relevant for the contemporary scholars writing on new media and can serve as a source for the inspiration or polemic. In this light, diachronic study of media shall not be neglected as it is possibly the tool to overcome the aura which has surrounded new media for decades and allows new media scholars to take a step back with a reference to the history and gain more critical insight.

\section{References}

Adorno, T. W. (2005). Minima moralia: Reflections on a damaged life. London: Verso.

Benjamin, W. (1982). The author as producer. In A.

${ }^{20}$ Lister et al. (2003) speaks in this relation about dynamic matrix. 
Arato, E. Gebhardt (Eds.), Essential Frankfurt school reader. New York: Continuum.

Benjamin, W. (2003). The work of art in the age of its technological reproducibility: Third version. In $\mathrm{H}$. Eiland, M. W. Jennings (Eds.), Walter Benjamin Selected Writings (pp. 251-283). Cambridge, MA: Harvard University Press.

Benthall, J. (1976). The body electric: Patterns of western industrial culture. London: Thames and Hudson.

Berelson, B. (1948). Communication and public opinion. In W. Schramm (Ed.), Communications in modern society (pp.167-185). Urbana, IL: University of Illinois Press.

Bimber, B. (1994). Three faces of technological determinism. In M. R. Smith, and L. Marx (Eds.), Does technology drive history: The dilemma of technological determinism (pp. 79-100). Massachusetts: MIT Press.

Blondheim, M., \& Watson, R. (2007). The Toronto School of communication theory: Interpretations, extensions, applications. Jerusalem: The Hebrew University Magnes Press.

Blondheim, M. (2007). "The Significance of communication" according to Harold Adams Innis. In R. Watson, and M. Blondheim (Eds), The Toronto School of communication theory: Interpretations, extensions, applications (pp.5382). Jerusalem: The Hebrew University Magnes Press.

Brecht, B. (1932). Der Rundfunk als Kommunikationsapparat. In Blätter des Hessischen Landestheaters, Darmstadt, July $16,1932$.

Brette, O. (2003). Thorstein Veblen's theory of institutional change: Beyond technological determinism. European Journal of the History of Economic Thought, 10 (3), 455478.

Bryant, J., and Oliver, M. B. (2009). Media effects: Advances in theory and research. New York: Routledge.

Bush, V. (1945). As we may think. Atlantic Monthly, 176 (1), 101-108.

Chandler, D. (1995). Technological or media determinism. Retrieved May 3, 2010 from 
http://www.aber.ac.uk/media/ Documents/tecdet/tecdet. html.

Chandler, D. (1996). Engagement with media: Shaping and being shaped. CMC magazine. Retrieved May 3, 2010 from http://www.aber.ac.uk/media/

Documents/short/determ.html.

De kerckhove, D. (1989). McLuhan and the "Toronto School of Communication. Canadian Journal of Communication, 14 (4), 73-79.

Deuze, M. (1999). Journalism and the web: An analysis of skills and standards in an online environment. Gazette, 61(5), 373-390.

Deuze, M. (2003). The web and its journalisms: Considering the consequences of different types of newsmedia online. New Media and Society, 5 (2), 203-230.

Douglas, S. (1987) Inventing American broadcasting: 18991922. Baltimore, MD: Johns Hopkins University Press.

Ellul, J. (1964). The technological society. New York: Alfred A. Knopf Inc.

Enzensberger, H. M. (1970) Constituents of a theory of the media. New Left Review, 64, 13-36.

Ferguson, M. (1986) The challenge of neo-technological determinism for communication systems of industry and culture. In M. Ferguson (Ed.), New communication technologies and the public interest: Comparative perspectives on policy and research (pp. 52-70). London: Sage Publications.

Ferkiss, V. C. (1969). Technological man: Myth and reality. New York: New American Library, Mentor Books.

Ferkiss, V. C. (1974). The future of technological civilization. New York: George Braziller.

Ferkiss, V. C. (1993). Nature, technology and society: Cultural roots of the currant environmental crisis. New York, London: New York University Press.

Fleck, J., and Howells, J. (2001). Technology, the technology complex and the paradox of technological determinism. Technology Analysis and Strategic Management, 13(4), 523-532. 
Green, J. (2002). Communication, technology and society. London, Thousand Oaks, New Delhi: SAGE Publications Ltd.

Habbermas, J. (1970). Toward a rational society: Student protest, science and politics. Boston: Beacon Press.

HavelocK, E. (1963). Preface to Plato. Cambridge, MA: Belknap press of Harvard university press.

Heilbroner, R. (2004). Do machines make history? In D. M. Kaplan (Ed.), Readings in the philosophy of technology (pp. 7-16). Lanham, Maryland: Rowman \& Littlefield Publishers Ltd.

Heilbroner, R. (1994). Technological determinism revisited. In M. R. Smith, and L. Marx (Eds.), Does technology drive history: The dilemma of technological determinism (pp. 67-78). Massachusetts: MIT Press.

Hickman, L. A. (1990). John Dewey's pragmatic technology. Bloomington, Indianapolis: Indiana University Press.

Innis, H. A. (2007). Empire and communication. Toronto, Tonawanda, NY: Dundurn Press.

Innis, H. A. (1964). The bias of communication. Introduction by M. McLuhan. Toronto: University of Toronto Press.

Jenkins, H. (2006). Convergence culture: Where old and new media collide. New York, London: New York University Press.

Jordan, T. (2008). Hacking: Digital media and technological determinism. Cambridge, Malden, MA: Polity Press.

Katz, E., and Lazarsfeld, P. F. (1955). Personal influence. Glencoe, IL: Free Press.

Kroker, A. (1984). Technology and the Canadian mind: Innis/McLuhan/Grant. Montreal: New World Perspectives.

Lappin, T. (1995). Déjà vu all over again, Wired, May, 174$177,218-222$.

Lazarsfeld, P. F., Berelson, B., and Gaudet, H. (1944). The people's choice: How the voter makes up his mind in a presidential campaign. New York: Duell, Sloan and Pearce. 
Levin, S. M. (1956). John Dewey's evaluation of technology. American Journal of Economics and Sociology, 15(2), 123-136.

Lievrouw, L. (2006). New media design and development: Fiffusion of innovations vs social shaping of techology. In L. A. Lievrouw, S. Livingstone (Eds.), The Handbook of New Media ( $2^{\text {nd }}$ ed) (pp. 246-265). London, Thousand Oaks, CA, New Delhi: SAGE Publications Ltd.

Lievrouw, L. A., and Livingston E. S. (Eds.) (2006). The handbook of new media ( $2^{\text {nd }}$ ed). London, Thousand Oaks, CA, New Delhi: SAGE Publications Ltd.

Lippmann, W. (1965). Public opinion. London: Macmillan.

Lister, M. et al. (2003). New media: A critical introduction. London: Routledge.

Mackenzie, D. A., and Wajcman, J. (1999). The social shaping of technology: How the refrigerator got its hum. Buckingham: Open University Press.

Manovich, L. (2001). The language of new media. Cambridge, MA: MIT Press.

Marcuse, H. (1982). Some social implications of modern technology. In A. Arato, and E. Gebhardt (Eds.), Essential Frankfurt School reader. New York: Continuum, pp. 138-162.

Marcuse, H. (1964). One-dimensional man: Studies in the ideology of advanced industrial society. Boston: Beacon Press.

Marshall, P. D. (2004). New media cultures. London: Arnold.

Marx, K. (2005). Poverty of philosophy. Adamant Media Corporation.

Mcmillan, S. J. (2002). Exploring models of interactivity from multiple research traditions: Users, documents, and systems. In L. A. Lievrouw, and S. Livingstone (Eds.), The handbook of new media (pp. 163-182). London, Thousand Oaks, New Delhi: Sage Publications.

McLuhan, M. (1964). Understanding media: The extensions of man. New York: McGraw-Hill.

Mcluhan, M. (2000). Člověk, média a elektronická kultura: Výbor z díla. Brno: Jota. 
McLuhan, M. (2002). The Gutenberg Galaxy. Toronto, Buffalo, London: University of Toronto Press.

Mcluhan, M., and Fiore, Q. (1967). Medium is the massage: An inventory of effects. New York: Bantam Books.

Mcluhan, M., and Watson, W. (1970). From cliché to archetype. New York: Viking Press.

Mcquail, D. (2010). McQuail's mass communication theory $\left(6^{\text {th }}\right.$ ed.). London, Thousand Oaks, California, New Delhi: SAGE Publications Ltd.

Meyrowitz, J. (1985). No sense of place: The impact of electronic media on social behaviour. Oxford: Oxford University Press.

Mumford, L. (1964). The myth of the machine, vol. 1: Technics and human development. New York: Harcourt Brace Jovanovich.

Mumford, L. (1970). The myth of the machine, vol. 2: The pentagon of power. New York: Harcourt Brace Jovanovich.

Negroponte, N. (1995). Being digital. New York: Vintage books.

Ong, W. J. (1982). Orality and literacy: The technologizing of the word. London, New York: Methuen.

Park, R. E. (1922). The immigrant press and its control. New York: Harper \& Brothers.

Park, R. E., and Burgess, E. W. (1967). The city: Suggestions for investigation of human behavior in the urban environment. Chicago, London: The University of Chicago Press, Ltd.

Park, R. E. (1940). Physics and society. Canadian Journal of Economics and Political Science, 6 (2), 135-152.

Park, R. E. (1955). Society: collective behavior, news and opinion, sociology and modern society. Collected papers, Volume 3. Glencoe, IL: Free Press.

Pool, I. S. (1983). Technologies of freedom: On free speech in an electronic age. Cambridge, MA: Belknap Press.

Poster, M. (1990). The mode of information: Poststructuralism and social control. Chicago: University of Chicago Press. 
Poster, M. (1999). Underdetermination. New Media and Society, 1 (1), 13-17.

Postman, N. (1979). Teaching as a conserving activity. New York: Delacorte Press.

Postman, N. (1993). Technopoly: The surrender of culture to technology. New York: Vintage Books.

Rakow, L. F. (1999). The public at the table: From public access to public participation. New Media and Society, 1(1),74-82.

Rice, R. E. (1984a). Development of new media research. In R. E. Rice (Ed.), The new media (pp. 15-31). Beverly Hills, CA, New Delhi, London: Sage Publications, Ltd.

Rice, R. E. (1984b). New media technology: Growth and integration. In: R. E. Rice (Ed.), The new media (pp. 3380). Beverly Hills, CA, New Delhi, London: Sage Publications, Ltd.

Rieginer, B. (2005). Technology and the culture of modernity in Britain and Germany 1890-1945. Cambridge, New York, Melbourne, Madrid, Delhi: Cambridge University Press.

Shannon, C. E., and Weaver, W. (1949). The mathematical theory of communication. Urbana, Illinois: University of Illinois Press.

Smith, M. R. (1994). Technological determinism in American culture. In M. R. Smith, and L. Marx (Eds.), Does technology drive history: The dilemma of technological determinism. Massachusetts: MIT PRESS, pp. 1-36.

Soules, M. (1996). Harrold Innis: Bias of communication and monopolies of power. Retrieved July 1, 2011, from http://www.media-studies.ca/articles/innis.htm.

Stamps, J. (2001). Unthinking modernity: Innis, McLuhan, and the Frankfurt School. Québec: McGill-Queens' University Press.

Thompson, J. B. (1995). the media and modernity: A social theory of the media. Stanford, Oxford: Polity Press.

Tönnies, F. (2002). Community and society. Mineola, NY: Courier Dover Publications.

Veblen, T. (1965). The engineers and the price system. New York: A. M. Keeley. 
70 Kohutova, Correlation between media and technology

Veblen, T. (1978). The theory of business enterprise. New Brunswick, NJ: Transaction.

Winner, L. (1977). Autonomous technology: Technics-out-ofcontrol as a theme in political thought. Cambridge, MA: MIT Press.

Ms. Kohutova is a Ph.D. candidate at the Institute of Communication Studies and Journalism, Faculty of Social Studies, Charles University in Prague. She currently works as a lawyer for Baker \& McKenzie in Prague, where she practices in the areas of information technology and intellectual property. 